\title{
Exploring Language Learning Strategies of Vietnamese University English and Non- English Majors
}

\author{
Viet Thi Nguyen \\ Hong Duc University, Thanh Hoa, Vietnam
}

\begin{abstract}
This study compares language learning strategies (LLS) and their frequencies between Vietnamese English and non-English majors. The Strategies Inventory of Language Learning (SILL) questionnaire from Oxford's 1990 taxonomy was employed as the main research instrument. The questionnaire was administered to 140 students at a public university in Vietnam. Semi-structured interviews with ten students of both groups were also carried out to provide more qualitative information. The data analysis involved descriptive and inferential statistics and manual interview transcription. Both groups of students used a wide range of LLS across six strategy groups with metacognitive strategy group use the most frequent and compensation the least frequent. A significant difference was shown in the ways both groups employed LLS $(p<.05)$. Results from this study can provide a solid foundation for educational administrators and practitioners to better support these students and can add to an overall theory of LLS in Asia.
\end{abstract}

Functioning as the main medium for international communication and to better prepare Vietnam to participate in the move towards globalization, English is widely taught as a compulsory subject at a large number of schools and universities in Vietnam. To help learners advance their English, understanding the LLS they use when learning English is essential because LLS are considered one of the most vital factors in determining language learners' success (Cotton, 1995; McDonough, 1995) and finding strategies is an important characteristic of successful learners (Hedge, 2000). There is a firm relationship between LLS and elements of learners' responsibility in taking charge of their own learning and self-efficacy (Oxford, 1990). The role of the teacher is important in teaching students ways to learn now that learning a language is a lifelong process (Cribb, 2000) and teaching students appropriate strategies can mold them to be more independent, autonomous, and committed to life-long learning (Lee \& Oxford, 2008).

This study explores LSS employed by Vietnamese English and non-English majors when they are learning English as a foreign language and investigates if significant differences exist between students' majors and learning strategy use. Understanding the ways both groups of students have learnt English can be helpful for educational institutions and teachers to better 
assist the students to learn English. Specifically, the present study addresses the following research questions:

- What LLS do the English and non-English majors report using? What strategies do they use the most and least frequently?

- Is there any significant difference between students' majors and the learning strategy use?

- What are similarities and differences in LLS employed between English and non-English majors?

\section{Literature Review}

\section{Definitions and Classifications of Language Learning Strategies}

Definitions of LLS. The learning strategy literature is not theoretically consistent, especially regarding strategy definitions and classifications. Scholars hold different viewpoints towards these matters (Cohen, 1990; Griffiths, 2008; O'Malley \& Chamot, 1990; Oxford, 1990; Wenden \& Rubin, 1987). Oxford (1990) considered LLS to be "specific actions" of learners (p. 8), whereas others defined it as any learner's sets of operations, steps, plans or routines (Wenden \& Rubin, 1987), special thoughts or behaviors (O'Malley \& Chamot, 1990) or a conscious process of stored, recallable and applicable information (Cohen, 1990) to strengthen their language learning. LLS are defined as "activities consciously chosen by learners for the purpose of regulating their own language learning" (Griffiths, 2008, p. 87). Although the definition may be controversial, Griffiths' (2008) has been chosen for this study because it reflects the meaning and the semantic components of the term "learning strategy" and it has the merit of breadth and precision (Wahyuni, 2013, p. 39).

Classification of LLS. Three main learning strategy approaches are those described by O'Malley and Chamot (1990), Oxford (1990), and Stern (1992). For the purposes of this study, the Oxford approach was selected because of its comprehensiveness (Ellis, 1999) and it is considered the most detailed and systematic strategy classification (Radwan, 2011). O'Malley and Chamot's (1990) and Stern's (1992) frameworks were not selected because the former focuses mainly on communication in language learning and factors such as learners' feelings are not mentioned, while the latter reveals some overlaps between groups of LLS. Specific tasks for each type of strategy are shown in the questionnaire in Appendix A.

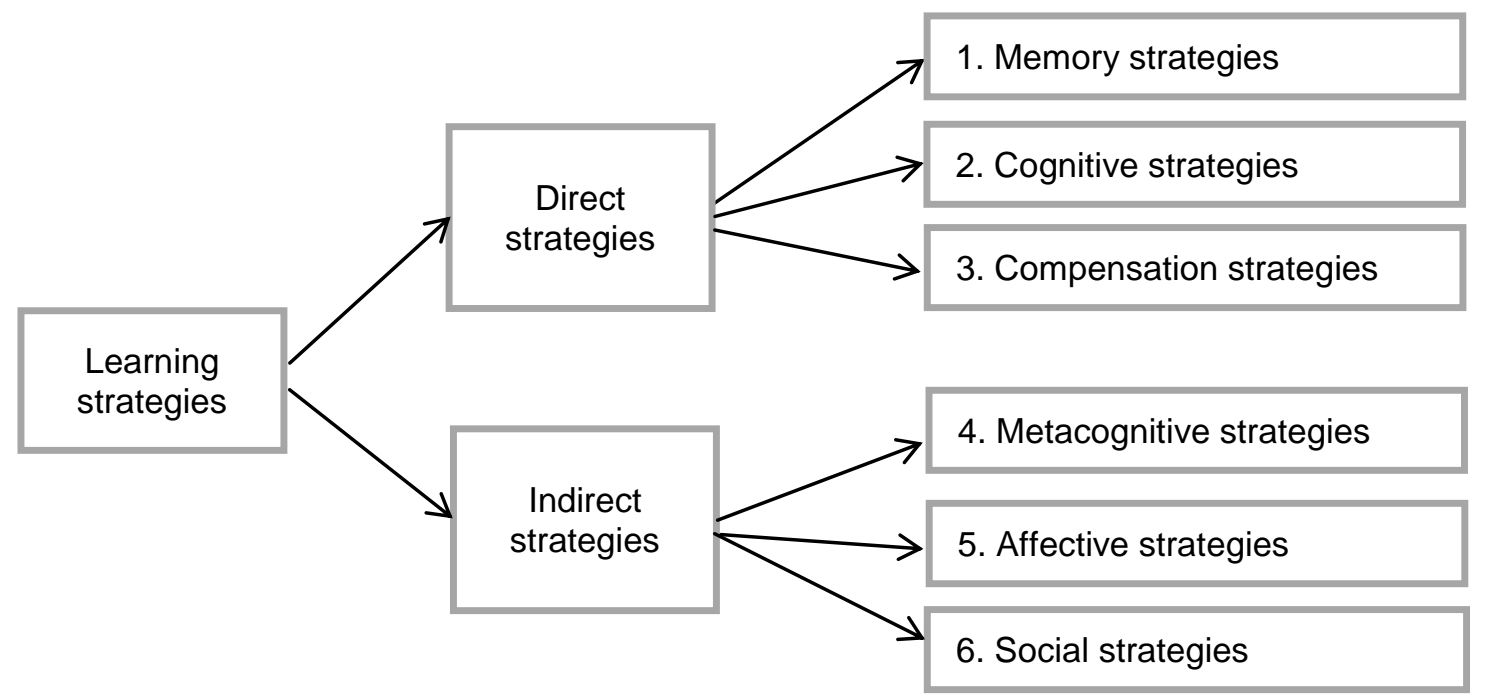

Figure 1. Diagram of a strategy system: Overview (Oxford, 1990, p. 16). 


\section{Major Differences in LLS Usage}

Most of the research on differences in the use of LLS tends to be focused on sub-categories of non-English majors such as arts versus science majors. However, results from these studies reveal inconsistencies. Some studies suggest that there exist significant differences between LLS of non-English majors such as industrial management versus engineering and political science majors (Alireza \& Abdullah, 2010), and computer science versus management information systems majors (McMullen, 2009). Nevertheless, in a study with 1,110 Korean students in middle school, high school, and university, when analyzing data from 558 students majoring in humanities and science / engineering, Lee and Oxford (2008) found that the major itself did not have any significant influence on learning strategy use $(p=.916>.05)$. These conflicting results confirm the need for clarity on whether or not differences between majors exist.

Regarding strategy usage, Chen (2005) investigated LLS of 134 students of both English majors and non-majors at a university in Taiwan using SILL questionnaires (Oxford, 1990). The results revealed that both groups used the compensation strategy group most frequently, the affective strategy group least frequently and English majors used LLS more frequently than non-English majors. The weakness of the study is that it appeared too descriptive while comparing the differences among variables (gender, major, and strategy use), and no inferential statistics were provided to show if there existed any significant relationships between these variables.

Tsan's (2008) study with 330 Taiwanese undergraduate university students, including 212 English and 118 non-English majors, addressed these limitations by employing both descriptive and inferential statistics. One similar finding to Chen's (2005) was that all subjects of the study employed compensation strategies most regularly and English majors used overall LLS with higher frequency compared to non-English majors. However, the most infrequently used strategy group was the affective group. The study also shows significant differences between the two groups in using overall LLS and within six sub-categories of LLS.

In the Vietnamese context, according to Hoang (2013), there are a surprising limited number of research studies on LLS employed by Vietnamese EFL learners. Studies conducted on LLS in the Vietnamese EFL context had a different focus of investigation (e.g., overall learning strategies or the most frequent strategies that the students reported to use). Hang (2008) examined the effect of variables on the choice of learning strategy use such as proficiency and gender. Little attention has been paid to non-English majors such as science-oriented students at the university level (Minh, 2012). Additionally, no research has placed the focus on comparing overall LLS between English and non-English majors in the context of Vietnam.

\section{Participants}

\section{Methodology}

In this study, participants were 140 Vietnamese EFL students, ages 19 to 22, from a large university located in central Vietnam. The participants came from different regions of Thanh Hoa Province. Half were English majors and the other half were non-English majors, namely business administration or finance and banking majors. Of the 140 questionnaires, two were incomplete and were eliminated. Of the 68 English major students, who were at the intermediate level of English proficiency, 32 were freshmen, 16 were in the second year, and 20 were in the third year. Fifty-one English majors were females and 17 were males. They had been studying English for three to ten years. Of the 70 non-English majors, all were first-year students, and all had been studying English for at least three years; there were 48 females and 22 males. They were all at the beginner level of English (see Table 1). All participants were chosen randomly to ensure objectivity. Ten participants, five English majors and five non- 
English majors, were chosen randomly for follow up interviews so that more information might provide a better understanding of the meaning of numbers in the questionnaire data.

Table 1

Participants' General Background

\begin{tabular}{|c|c|c|c|c|c|}
\hline & Total & Gender & Major & Year & $\begin{array}{c}\text { English } \\
\text { Proficiency }\end{array}$ \\
\hline $\begin{array}{l}\text { English } \\
\text { majors }\end{array}$ & $\begin{array}{c}68 \\
\text { (2 questionnaires } \\
\text { were eliminated) }\end{array}$ & $\begin{array}{l}51 \text { females } \\
17 \text { males }\end{array}$ & - English & $1^{\text {st }}, 2^{\text {nd }}$, and & Intermediate \\
\hline $\begin{array}{l}\text { Non- } \\
\text { English } \\
\text { majors }\end{array}$ & 70 & $\begin{array}{l}48 \text { females } \\
22 \text { males }\end{array}$ & $\begin{array}{l}\text { - Finance and } \\
\text { Banking } \\
\text { - Business } \\
\text { Administration }\end{array}$ & $1^{\text {st }}$ only & Beginner \\
\hline Total & 138 & & & & \\
\hline
\end{tabular}

\section{Procedure, Data Collection, and Analysis}

Quantitative and qualitative methods were used with a two-phase sequential procedure explanatory design (Creswell \& Plano Clark, 2007), such that the quantitative study was conducted first, followed by the qualitative study to build on the quantitative results. Generally, the quantitative data has greater weight. A quantitative method was employed to explore learning strategy use by the students; a qualitative method was used to better understand the meaning.

The quantitative data was collected using a SILL questionnaire from Oxford (1990; Version 7). The questionnaire consists of 50 items across six strategy groups. These items were made up of nine statements for the memory strategy group, ten for the cognitive strategy group, six for the compensation strategy group, nine for metacognitive strategy group, six for the affective strategy group; and six for the social strategy group. The statistical software SPSS (V. 22) was used to analyze the data. To answer the three research questions, the frequencies, means $(M)$, and standard deviations $(S D)$ of LLS and Spearman's rho two-tailed tests were calculated using descriptive statistics and an independent samples $t$-test. The statistical significance of .05 was set for the study. The mean scores were interpreted using the five-point Likert scale: 3.50 to 5.00 is high use; 2.50 to 3.49 , medium use; and 1.00 to 2.49 , low use.

Qualitative data was collected through semi-structured interviews in person with five students from each group over ten minutes. The interviews were in Vietnamese to ensure that the students had no language difficulty in answering the questions. The interviews were recorded with the participants' permission and later transcribed verbatim and carefully checked by the researcher individually. For analysis, the transcription was coded by grouping strategies used by the students to learn English vocabulary and four skills (listening, reading, speaking, and writing), as well as their reasons for studying English.

\section{Reliability of the Questionnaire}

With the purpose of minimizing errors and biases in the study, the questionnaire and the interview guide were piloted. In this study, the reliability scores of the whole questionnaires for English majors and non-English majors are 0.92 and 0.94 respectively, which are much higher compared to the reliability coefficient of 0.70 recommended in most social science research 
situations (Santos, 1999). The reliability coefficient for each sub-category of LLSs for both groups was also no less than 0.80 .

\section{Results}

\section{Overall LLS Usage and Frequency of LLS Usage}

The results from the questionnaires show that all LLS mentioned in the SILL questionnaire across six strategy groups were reported to be employed by both the English and non-English majors.

Table 2

Frequency of Strategy Groups Used by English and Non-English Majors

\begin{tabular}{clccclcc}
\hline & \multicolumn{2}{c}{$\begin{array}{c}\text { English majors } \\
(n=68)\end{array}$} & & \multicolumn{5}{c}{$\begin{array}{c}\text { Non-English majors } \\
(n=70)\end{array}$} \\
\hline Ranking & Strategy Groups & Mean & $S D$ & Ranking & Strategy Groups & Mean & $S D$ \\
\hline 1 & Metacognitive & 3.79 & 0.49 & 1 & Metacognitive & 3.12 & 0.70 \\
\hline 2 & Social & 3.57 & 0.54 & 2 & Affective & 2.82 & 0.72 \\
\hline 3 & Cognitive & 3.45 & 0.70 & 3 & Social & 2.81 & 0.67 \\
\hline 4 & Memory & 3.33 & 0.55 & 4 & Cognitive & 2.78 & 0.63 \\
\hline 5 & Affective & 3.29 & 0.66 & 5 & Memory & 2.76 & 0.59 \\
\hline 6 & Compensation & 3.15 & 0.69 & 6 & Compensation & 2.70 & 0.60 \\
\hline
\end{tabular}

As can be seen from Table 2, the two strategy groups used at a high level of frequency for the English majors were metacognitive $(M=3.79 ; S D=0.49)$ and social $(M=3.57 ; S D=0.54)$. They were followed by cognitive, memory, affective, and compensation respectively at medium level of frequency. Non-English majors also used the metacognitive strategy most frequently, however, at a medium level of frequency. All the other strategy groups were also at the medium frequency level.

\section{Most and Least Frequently Used Learning Strategies}

An interesting finding is that non-English majors reported to use the metacognitive group most frequently, but of the 50 itemized strategies, the two most frequently used strategies belonged to the cognitive group. Both groups of the students reported to use the affective strategy / write down my feelings in a language learning diary and the compensation strategy I make up new words if I do not know the right ones in Eng/ish the least frequently, at a low level. Tables 3 and 4 display the two most and least used strategies employed by both groups of the students.

\section{Table 3}

\section{Most Frequently Used Learning Strategies}

\begin{tabular}{|c|c|c|c|}
\hline English majors $(n=68)$ & Category & Rank & Mean \\
\hline 33. I try to find out how to be a better learner of English. & Metacognitive & 1 & 4.26 \\
\hline 32. I pay attention when someone is speaking in English. & Metacognitive & 2 & 4.10 \\
\hline \multicolumn{4}{|l|}{ Non-English majors $(n=70)$} \\
\hline 10. I say or write new English words several times. & Cognitive & 1 & 3.66 \\
\hline 32. I pay attention when someone is speaking in English. & Cognitive & 1 & 3.66 \\
\hline
\end{tabular}


Table 4

Least Frequently Used Learning Strategies

\begin{tabular}{|c|c|c|c|}
\hline English majors $(n=68)$ & Category & Rank & Mean \\
\hline $\begin{array}{l}\text { 26. I make up new words if I do not know the right ones in } \\
\text { English. }\end{array}$ & Compensation & 1 & 2.06 \\
\hline 43. I write down my feelings in a language learning diary. & Affective & 2 & 2.18 \\
\hline \multicolumn{4}{|l|}{ Non-English majors $(n=70)$} \\
\hline 43. I write down my feelings in a language learning diary. & Affective & 1 & 1.66 \\
\hline $\begin{array}{l}\text { 26. I make up new words if I do not know the right ones in } \\
\text { English. }\end{array}$ & Compensation & 2 & 2.07 \\
\hline
\end{tabular}

\section{Major Differences in Using LLS}

An independent sample $t$-test was run to see if there is a significant difference between English and non-English majors in using LLS. It can be seen from Table 5 that the relationship between the two variables was significant $(p=.000<.05)$. Also, $p=.000<.05$ for all sub-types of strategy use indicates that both groups of students used not only overall LLS but also sub-types of LLS differently from each other, with non-English majors being more infrequent employers of LLS.

Table 5

Correlations Between Major and Overall Learning Strategy Use and Its Subcategories

\begin{tabular}{llc}
\hline & & \multicolumn{1}{c}{ Sig. (two-tailed) } \\
\hline Overall LLS use & & .000 \\
\hline & Memory & .000 \\
\cline { 2 - 3 } Sub-categories of LLS & Cognitive & .000 \\
\cline { 2 - 3 } & Compensation & .000 \\
\cline { 2 - 3 } & Metacognitive & .000 \\
\cline { 2 - 3 } & Affective & .000 \\
\cline { 2 - 3 } & Social & .000 \\
\hline
\end{tabular}

Note: Independent variable: major (English and non-English majors); $N=138 ; p<0.05$.

As illustrated in Table 6, first year English majors used overall LLS and sub-categories of LLS more frequently than first year non-English majors and the difference in using LLS by both groups was significant $(p<0.05)$. The first-year English majors used the cognitive, metacognitive, and social groups at a high level of frequency, and the non-English majors did not use any strategy groups at a high frequency. 


\section{Table 6}

Frequency of Strategy Group Use by First-Year English and Non-English Majors, Correlations Between Majors and Learning Strategy Use and Its Subcategories

\begin{tabular}{lccccc}
\hline Strategies & \multicolumn{2}{c}{$\begin{array}{c}\text { English majors } \\
\text { freshmen } \\
(n=32)\end{array}$} & $\begin{array}{c}\text { Non-English majors } \\
\text { freshmen } \\
(n=70)\end{array}$ & Sig. \\
\cline { 2 - 5 } & $M$ & $S D$ & $M$ & $S D$ & (two-tailed) \\
\hline Memory & 3.45 & 0.49 & 2.76 & 0.59 & .000 \\
\hline Cognitive & 3.58 & 0.56 & 2.78 & 0.63 & .000 \\
\hline Compensation & 3.21 & 0.75 & 2.70 & 0.60 & .001 \\
\hline Metacognitive & 3.96 & 0.51 & 3.12 & 0.70 & .000 \\
\hline Affective & 3.31 & 0.73 & 2.82 & 0.72 & .002 \\
\hline Social & 3.65 & 0.70 & 2.81 & 0.67 & .000 \\
\hline
\end{tabular}

Note: $p<0.05$.

Table 7 shows that there was no significant difference between the first-, second- and third-year English majors in general $(p<.05)$, except for cognitive and metacognitive strategy groups when comparing the first- and second-year students. This difference was also found in the use of cognitive strategies between the first and third-year students.

Table 7

Strategies Used by First, Second, and Third-Year English Majors

\begin{tabular}{|c|c|c|c|c|c|c|c|c|c|}
\hline \multirow[t]{2}{*}{$\begin{array}{l}\text { Strategy } \\
\text { groups }\end{array}$} & \multicolumn{2}{|c|}{$\begin{array}{c}1^{\text {st }} \text { year } \\
\text { students } \\
(n=32)\end{array}$} & \multicolumn{2}{|c|}{$\begin{array}{l}2^{\text {nd }} \text { year } \\
\text { students } \\
(n=16)\end{array}$} & \multicolumn{2}{|c|}{$\begin{array}{l}3^{\text {rd }} \text { year } \\
\text { students } \\
(n=20)\end{array}$} & \multirow[t]{2}{*}{$P 1$} & \multirow[t]{2}{*}{$P 2$} & \multirow[t]{2}{*}{ P3 } \\
\hline & $M$ & $S D$ & $M$ & $S D$ & $M$ & $S D$ & & & \\
\hline Memory & 3.45 & .49 & 3.33 & .41 & 3.35 & .44 & .419 & .497 & .869 \\
\hline Cognitive & 3.58 & .56 & 3.07 & .39 & 3.41 & .51 & .002 & .259 & .038 \\
\hline Compensation & 3.21 & .75 & 3.02 & .68 & 3.16 & .64 & .401 & .805 & .535 \\
\hline Metacognitive & 3.96 & .51 & 3.55 & .50 & 3.70 & .55 & .011 & .080 & .416 \\
\hline Affective & 3.31 & .73 & 3.30 & .55 & 3.26 & .65 & .960 & .787 & .832 \\
\hline Social & 3.65 & .70 & 3.50 & .73 & 3.50 & .67 & .490 & .443 & 1.00 \\
\hline
\end{tabular}

Note: $P 1$ compares 1 st \& 2nd year students; P2 compares 1st \& 3nd year students; $P 3$ compares 2 nd \& 3 rd year students; $p<.05$.

One crucial finding from analyzing the interview transcription of ten participants showed that both groups of students used a variety of strategies in acquiring English. This finding confirms the results from the quantitative analysis that all strategies mentioned in the questionnaire were used by the students of both groups. Additionally, the qualitative data revealed reasons why the students learn English and use the strategies.

Among five randomly selected English majors (S1, S2, S3, S4, S5) participating in the interviews, S1 and S2 reported to use flashcards, S3 and S4 used the strategy of "writing down new words repeatedly" to learn vocabulary; and S3, S4, and S5 reported learning English words through listening to English songs, reading magazines, and watching English videos on the Internet. To 
strengthen their English skills, various ways were applied such as speaking in front of the mirror (S4), and using YouTube and / or social networks (S2, S3).

Similarly, non-English majors reported learning English vocabulary and English skills by writing down the words repeatedly $(\mathrm{S} 6, \mathrm{~S} 7)$, using flash cards $(\mathrm{S} 7, \mathrm{~S} 8)$ or using imagination, using social networks, watching TV, and listening to music (S9, S10). S7 explained his way of learning and provided the reason for choosing this learning method: "Now I am using flash cards to learn new words. I stick these cards on the things in my room so that I can see them every day. I think it helps me remember new words better."

Responding to the question of why the students learn English, the majority of the English majors said they learn English because it is very interesting and because English is the key to advance their knowledge and to have a good job in the future. All non-English majors also agreed that English is important for future job opportunities, but what they paid more attention to was "studying for exams" since English is a compulsory subject for their course.

\section{Discussion}

The first finding is that the adult students of English and non-English in this study used various LLS spread over six strategy groups identified in Oxford's 1990 taxonomy. The overall mean scores of LLS used by both groups of students were at medium level of frequency. The results are supported by many studies in EFL contexts (Chen, 2005; Lee \& Oxford, 2008; Tsan, 2008). This suggests LLS play a significant role in students' learning of a language and that the learners are aware of using strategies to enhance their learning.

Significant difference was found between major and strategy use. English majors used strategies differently and more frequently than non-English majors as in Chen (2005) and Tsan (2008). The reason may be that English is an interesting and core subject for English majors now and likely they will use English for their future careers; therefore, they should acquire it to the fullest extent. The reason for non-English majors to use strategies in learning English may be because they wanted to pass the TOEIC test to graduate. It can be concluded that the teaching and learning English for English majors is quite successful because the students have a clear goal for their study and are better motivated. However, the teaching and learning in this research context reveals difficulties when motivations for the non-English majors to study English are external motivation (future jobs, final exams).

One finding is that the metacognitive strategy group was used most frequently by the students. When students use metacognitive strategies most frequently for coordinating the learning process to achieve their goal, it may indicate a good sign of learning English as students will be more motivated and gain more if they have a goal to work towards (Hom \& Murphy, 1983). Compensatory strategy use ranked the lowest amongst the six strategy groups. This result contradicts the findings of other studies in EFL contexts (Chen, 2005; Lee \& Oxford, 2008). One possible reason could be the interference of culture and educational system factors. Shmais (2003) took Palestine as an example: due to the constraints of curriculum (exams and textbooks) and big class size, students in Palestine have had few chances to employ functional practice strategies which results in their hesitation in using compensation strategies.

Two top frequent strategies that English majors used are I try to find out how to be a better learner of English $(M=4.26)$ and I pay attention when someone is speaking in English $(M=$ 4.01). This means that English majors recognised the importance of English and pay a great deal of attention to discover ways to advance their English. Non-English majors seem to not have as applicable plans for their whole learning process, but were more likely to pay attention 
to actual tasks the teachers gave them. Along with I pay attention when someone is speaking in English $(M=3.66)$, I say or write new words several times $(M=3.66)$ was also the most often used strategy by non-English majors as they had to take the TOEIC test. The two least frequent strategies that both groups of the students used were I make up new words if I do not know the right ones in English and I write down my feelings in a language learning diary. All students reported using these strategies at a low level. Writing in English is considered the most difficult skill for not only Vietnamese EFL learners to master but also for many learners in other EFL contexts. This was evidenced by the lowest average scores for the writing of Vietnamese and other EFL learners taking the IELTS academic test in 2015 ("Test taker performance," 2015). The reason for the low quality in English writing of EFL learners may be a poor habit of freewriting every day; therefore, instructions for a process of freewriting need to be provided so that students learn how to initiate their writing and write well (Chen, 2005). For example, teachers should encourage and instruct students to frequently write down their feelings freely in a language learning diary.

The findings show that English majors have a higher overall mean value of all LLS used to learn English than non-English majors. Additionally, the mean values for English majors employing each LLS were higher than those of non-English majors. This indicates that English majors have a better awareness of using English learning strategies and used them more actively.

The findings from the present study derived from answers of students from just a particular university in the country where the researcher played a dual role as a teacher and a researcher. Future research, thus, should involve a larger number of students at various universities in the Vietnamese context so that a broader view of Vietnamese students' LSS can be drawn. Additionally, the number of English and non-English majors should have been more wellbalanced in terms of years of study and students' language proficiency levels should have been approximately equal. Regarding research instruments, in addition to questionnaires and semistructured interviews, observations and learning diaries should be used to maximize the validity of the study.

\section{Conclusion}

This study examined LLS of Vietnamese English and non-English majors. The results reveal that overall, students were using all strategies in the SILL questionnaire. The most frequent and infrequent use of LLS employed by both groups belongs to the metacognitive and compensation strategy groups respectively. The students' major reflects a significant relationship with learning strategy use. Future research in this field may take the form of action research in which researchers plan and teach students English learning strategies, observe, and reflect on the research idea to see how teaching LLS influences learners' study of English.

\section{Implications for the Teaching and Learning of English in EFL Contexts}

Findings from this study suggest that strategy training would be advantageous for students in English learning as a foreign language. Training LLS would become more effective with the recognition of education authorities and teachers.

For education authorities, training courses on teaching LLS could be provided for teachers before it is carried out in the real classroom. Formal training and / or training through workshops on LLS could be carried out so that teachers can raise their awareness and skills of teaching LLS for students. A certain amount of time (e.g., two hours) could be allowed in the curriculum to teach LLS. 
For teachers, if time is given to insert strategy training sessions, it may be significant to raise students' consciousness of using LLS such as brainstorming techniques that they used for an oral task in the past. According to Rubin, Chamot, Harris, and Anderson (2007), such brainstorming techniques can help students explore a variety of their classmates' LLS, and this can motivate them to try out new strategies.

Teachers can also encourage non-English majors to use LLS more frequently, especially the strategies that English majors employed with high level of frequency because English majors can be considered better learners of English. For instance, non-English majors may benefit from more frequently practicing the cognitive strategy / read for pleasure in English $(M=2.49)$ and the metacognitive strategy / look for people / can talk to in English $(M=2.70)$, which were being used with a high level of frequency by English majors $(M=3.65$ and $M=3.56$ respectively). It is also essential to note that English majors and non-English majors also have differences between LLS and motivation to learn English; therefore, teachers should apply different teaching techniques and activities to best support them. Additionally, less frequent compensation strategies should be practiced with higher levels of frequency by both English and non-English majors since compensation strategies are claimed to help learners correctly guess meaning without having much English grammar and lexicology (Yang, 2007).

\section{Author Note}

Viet Thi Nguyen, Faculty of Foreign Languages, Hong Duc University, Thanh Hoa, Vietnam.

Viet is currently a lecturer of English at Hong Duc University. She holds a Master's degree in TESOL / Foreign Language Teaching from the University of Canberra, Australia. Her research interests include learning strategies and learner autonomy.

Correspondence concerning this article should be addressed to Viet Thi Nguyen, Faculty of Foreign Languages, Hong Duc University, No. 307 Le Lai Street, Thanh Hoa City, Vietnam. E-mail: nguyenvietk6@gmail.com 


\section{References}

Alireza, S., \& Abdullah, M. H. (2010). Language learning strategies and styles among Iranian engineering and political science graduate students studying abroad. Educational Research and Reviews, 5(2), 35-45. Available at http://www.academicjournals.org/journal/ERR/article-full-text-pdf/C8C5F403793

Chen, Y. (2005). The learning strategies of Taiwanese university students: English majors versus non-English majors and males versus females. Indonesian Journal English Language Teaching, 2, 203-219.

Cohen, A. (1990). Language learning: Insights for learners, teachers, and researchers. New York, NY. Newbury House.

Cotton, J. (1995). The theory of learning strategies: An introduction. London, Great Britain: Kogan Page.

Creswell, J. W., \& Plano Clark, V. L. (2007). Designing and conducting mixed methods research. Thousand Oaks, CA: Sage.

Cribb, M. V. (2000). Learner intervention in the language classroom. The Language Teacher, 24(10), 9-12. Retrieved from http://jalt-publications.org/old_ttt/articles/2000/10/cribb

Ellis, R. (1999). The study of second language acquisition. Oxford, England: Oxford University Press.

Griffiths, C. (2008). Lessons from good language learners. Cambridge, England: Cambridge University Press.

Hằng, D. T. (2008). Vocabulary learning strategies employed by students at Hung Vuong Gifted High School. Unpublished Master of Arts Thesis. Master of Arts Thesis. College of Foreign Language, VNU, Vietnam.

Hedge, T. (2000). Teaching and learning in the language classroom. Oxford, England: Oxford University Press. Retrieved from http://www.birmingham.ac.uk/Documents/collegeartslaw/cels/essays/secondlanguage/essayGLLSThompson.pdf

Hoang, T. B. N. (2013). English learning strategies of Vietnamese tertiary students. Unpublished doctoral dissertation, University of Tasmania, Australia. Retrieved from http://eprints.utas.edu.au/17105/1/Front-Nguyen-Thesis-_2013.pdf

Hom, H. L., Jr., \& Murphy, M. D. (1983). Low need achievers' performance: The positive impact of a self-directed goal. Personality and Social Psychology Bulletin, 11, 275-285. http://dx.doi.org/10.1177/0146167285113004

Lee, K. R. \& Oxford, R. (2008). Understanding EFL learners' strategy use and strategy awareness. Asian EFL Journal, 10(1), 7-32. Available at http://asian-efljournal.com/march_2008_ebook.pdf

McDonough, S. H. (1995). Strategy and skill in learning a foreign language. London, Great Britain: Edward Arnold.

McMullen, M. G. (2009). Using language learning strategies to improve the writing skills of Saudi EFL students: Will it really work? System, 373), 418-433. http://dx.doi.org/10.1016/j.system.2009.05.001

Minh, D. D. (2012). Language learning strategies employed by EFL science-oriented university students in Vietnam: An exploratory study. International Journal of Scientific and Research Publications, 2(4), 1-5.

O’Malley, J. M., \& Chamot, A. U. (1990). Learning strategies in second language acquisition. New York, NY: Cambridge University Press. http://dx.doi.org/10.1017/CBO9781139524490

Oxford, R. L. (1990). Language learning strategies: What every teacher should know. New York, NY: Newbury House. 
Radwan, A. A. (2011). Effects of L2 proficiency and gender on choice of language learning strategies by university students majoring in English. Asian EFL Journal, 13(1), 115-163. Available at http://www.asian-efl-journal.com/PDF/March-2011-aar.pdf

Rubin, J., Chamot, A. U., Harris, V., \& Anderson, N. J. (2007). Intervening on the use of strategies. In A. D. Cohen \& E. Macaro (Eds.), Language learner strategies: 30 years of research and practice. (pp. 29-45). Oxford, UK: Oxford University Press.

Santos, J. R. A. (1999). Cronbach's Alpha: A tool for assessing the reliability of scales. Journal of Extension, 3オ(2), 1-4. Available at http://www.joe.org/joe/1999april/tt3.php/

Shmais, W. A. (2003). Language learning strategy use in Palestine. TESL-EJ 72 ), 3-13. http://www.tesl-ej.org/wordpress/issues/volume7/ej26/ej26a3/

Stern, H. H. (1992). Issues and options in language teaching. Oxford, England: Oxford University Press.

Test taker performance. (2015). Retrieved from https://www.ielts.org/teaching-and-research/testtaker-performance

Tsan, S. C. (2008). Analysis of English learning strategies of Taiwanese students at national Taiwan normal university. Educational Journal of Thailand, 2(1), 84-94. Retrieved from http://digital_collect.lib.buu.ac.th/ojs/index.php/Education3/article/view/1628

Wahyuni, S. (2013). Learning strategies for speaking skills employed by Indonesian EFL tertiary students across proficiency and gender. Unpublished doctoral dissertation, University of Canberra, Canberra, Australia.

Wenden, A. \& Rubin, J. (1987). Learner strategies in language learning. Englewood Cliffs, NJ: Prentice Hall.

Yang, M. N. (2007). Language learning strategies for junior college students in Taiwan: Investigating ethnicity and proficiency. Asian EFL Journal, 9(2), 35-57. Available at http://asian-efl-journal.com/1051/quarterly-journal/2007/06/language-learningstrategies-for-junior-college-students-in-taiwan-investigating-ethnicity-and-proficiency/ 
Appendix A

Learning Strategies in SILL (Oxford, 1990)

Used by Vietnamese EFL English and Non-English Majors

\begin{tabular}{|c|c|c|c|c|c|c|}
\hline \multirow{2}{*}{ 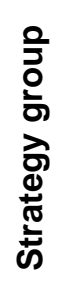 } & \multirow{2}{*}{$\stackrel{\varepsilon}{\Phi}$} & \multirow{2}{*}{ L2 speaking strategies } & \multicolumn{2}{|c|}{$\begin{array}{l}\text { English majors } \\
\qquad(n=68)\end{array}$} & \multicolumn{2}{|c|}{$\begin{array}{l}\text { Non-English } \\
\text { majors } \\
(n=70)\end{array}$} \\
\hline & & & Mean & $S D$ & Mean & $S D$ \\
\hline \multirow{9}{*}{ 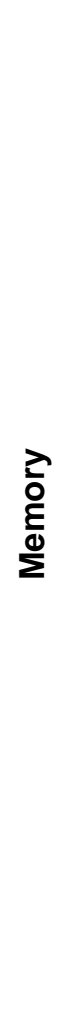 } & 1. & $\begin{array}{l}\text { I think of relationships between what I } \\
\text { really know, and new things I learn in } \\
\text { English. }\end{array}$ & 3.16 & 0.87 & 2.79 & 0.93 \\
\hline & 2. & $\begin{array}{l}\text { I use new English words in a sentence so I } \\
\text { can remember them. }\end{array}$ & 3.74 & 0.77 & 3.01 & 0.93 \\
\hline & 3. & $\begin{array}{l}\text { I connect the sound of a new English word, } \\
\text { and an image or picture of the word to help } \\
\text { remember the word. }\end{array}$ & 3.41 & 1.12 & 2.81 & 1.07 \\
\hline & 4. & $\begin{array}{l}\text { I remember a new English word by making } \\
\text { a mental picture of a situation in which the } \\
\text { word might be used. }\end{array}$ & 3.49 & 0.94 & 2.79 & 1.09 \\
\hline & 5. & $\begin{array}{l}\text { I use rhymes to remember new English } \\
\text { words. }\end{array}$ & 2.69 & 1.06 & 2.7 & 1.07 \\
\hline & 6. & $\begin{array}{l}\text { I use flashcards to remember new English } \\
\text { words. }\end{array}$ & 3.9 & 1.04 & 2.91 & 1.05 \\
\hline & 7. & I physically act out new English words. & 2.97 & 1.02 & 2.1 & 0.85 \\
\hline & 8. & I review English lessons often. & 3.79 & 0.82 & 3.06 & 0.81 \\
\hline & 9. & $\begin{array}{l}\text { I remember new English words or phrases } \\
\text { by remembering their location on the page, } \\
\text { on the board, or on the street sign. }\end{array}$ & 2.87 & 1.19 & 2.63 & 1.16 \\
\hline \multirow{8}{*}{ 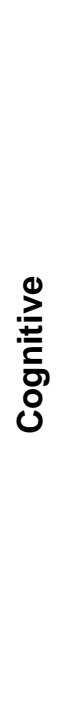 } & 10. & $\begin{array}{l}\text { I say or write new English words several } \\
\text { times. }\end{array}$ & 3.91 & 0.88 & 3.66 & 0.85 \\
\hline & 11. & I try to talk like native English speakers. & 3.69 & 0.1 & 3.13 & 1.13 \\
\hline & 12. & I practice the sounds of English. & 3.57 & 0.85 & 2.81 & 0.95 \\
\hline & 13. & $\begin{array}{l}\text { I use English words I know in different } \\
\text { ways. }\end{array}$ & 3.21 & 1.02 & 2.63 & 1.16 \\
\hline & 14. & I start a conversation in English. & 3.31 & 0.83 & 2.46 & 0.96 \\
\hline & 15. & $\begin{array}{l}\text { I watch English language TV shows } \\
\text { spoken in English or go to movies spoken } \\
\text { in English. }\end{array}$ & 3.71 & 1.01 & 2.83 & 1.15 \\
\hline & 16. & I read for pleasure in English. & 3.65 & 1.02 & 2.49 & 1 \\
\hline & 17. & $\begin{array}{l}\text { I write notes, messages, letters, or reports } \\
\text { in English. }\end{array}$ & 3.03 & 1 & 2.17 & 0.97 \\
\hline
\end{tabular}




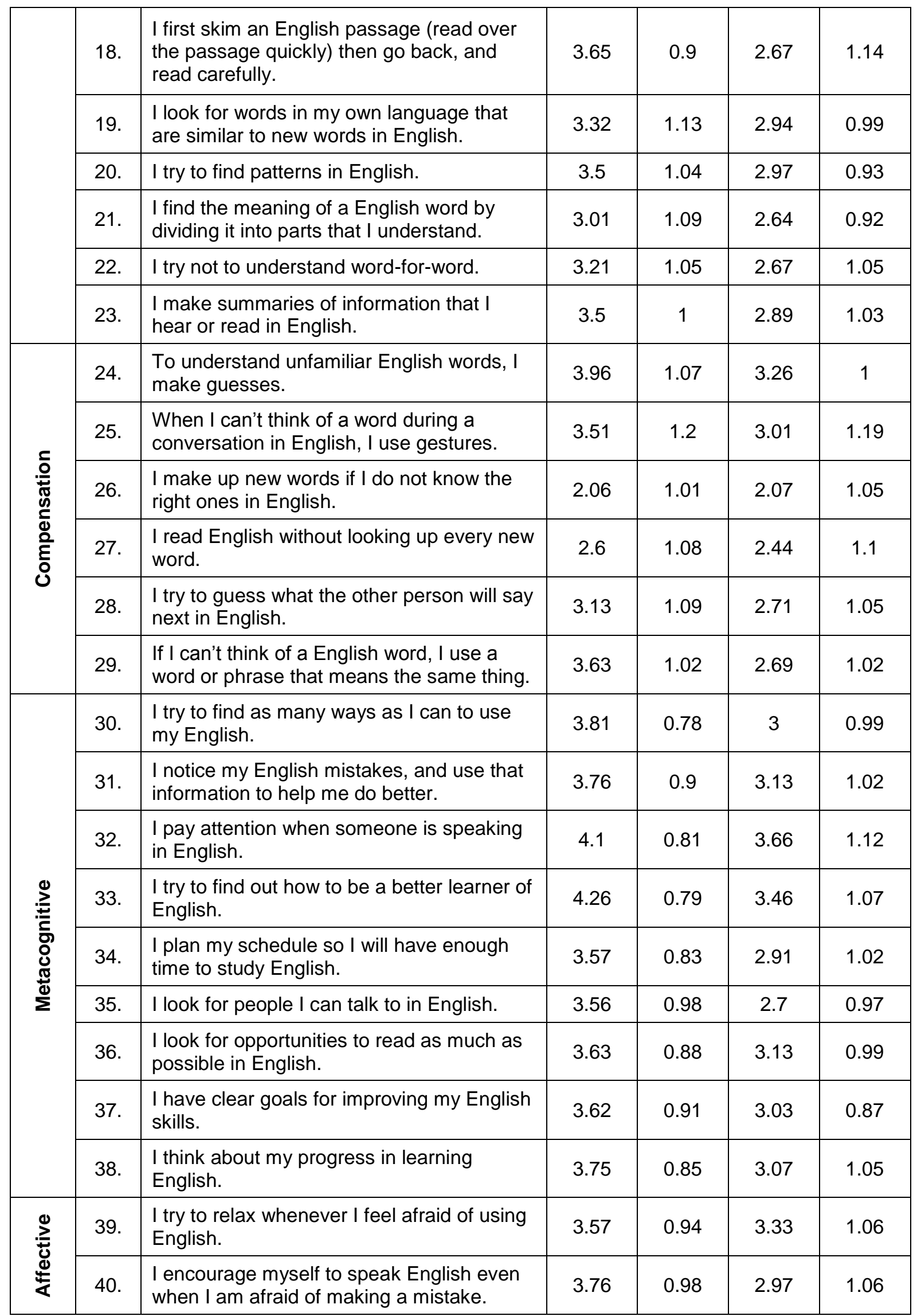




\begin{tabular}{|c|c|c|c|c|c|c|}
\hline & 41. & $\begin{array}{l}\text { I give myself a reward or treat when I do } \\
\text { well in English. }\end{array}$ & 3.38 & 1.16 & 2.89 & 1.12 \\
\hline & 42. & $\begin{array}{l}\text { I notice if I am tense or nervous when I am } \\
\text { studying or using English. }\end{array}$ & 3.49 & 1.17 & 3.14 & 1.09 \\
\hline & 43. & $\begin{array}{l}\text { I write down my feelings in a language } \\
\text { learning diary. }\end{array}$ & 2.18 & 0.96 & 1.66 & 0.78 \\
\hline & 44. & $\begin{array}{l}\text { I talk to someone else about how I feel } \\
\text { when I am learning English. }\end{array}$ & 3.38 & 1.13 & 2.91 & 1.23 \\
\hline \multirow{6}{*}{ 严 } & 45. & $\begin{array}{l}\text { If I do not understand something in English, } \\
\text { I ask the other person to slow down or say } \\
\text { it again. }\end{array}$ & 3.97 & 0.96 & 3.21 & 0.98 \\
\hline & 46. & $\begin{array}{l}\text { I ask English speakers to correct me when } \\
\text { I talk. }\end{array}$ & 2.68 & 1.24 & 2.3 & 1.05 \\
\hline & 47. & I practice English with other students. & 3.9 & 0.98 & 2.71 & 1.01 \\
\hline & 48. & I ask for help from English speakers. & 3.91 & 0.93 & 3.3 & 0.93 \\
\hline & 49. & I ask questions in English. & 3.63 & 0.96 & 2.93 & 1.05 \\
\hline & 50. & $\begin{array}{l}\text { I try to learn about the culture of English } \\
\text { speakers. }\end{array}$ & 3.34 & 1.13 & 2.7 & 1.17 \\
\hline \multicolumn{3}{|r|}{ Overall } & 3.45 & 0.96 & 2.84 & 1.02 \\
\hline
\end{tabular}




\section{Appendix B \\ Interview Guide on Language Learning Strategies \\ (English Version)}

\section{Introduction}

Hello! My name is Viet. I am conducting research on the overall learning strategies of English majors and non-majors at Hong Duc University. Thank you for coming today. The interview will last about 10 minutes. The interview will be recorded and will remain strictly confidential. Extracts from the interview may appear in my research report but under no circumstances will your name or any identifying characteristics be included. Your participation is totally voluntary; you are free to withdraw from the interview at any time or decline to answer any of the questions.

\section{Background Information}

1. What is your name?

2. What is your major?

3. Do you find learning English difficult?

\section{Content Information}

4. Is English important for you? Why do you study English?

5. What is your difficulty in learning English in general?

6. How do you learn new words in English?

7. How do you learn English grammar?

8. How do you improve your English pronunciation?

9. How do you improve your English speaking?

10. How do you improve your English reading?

11. How do you improve your English listening?

12. How do you improve your English writing?

13. Do you think using strategies can help you better your English? 